\title{
PEMBUATAN VIDEO MOTION GRAPHIC DATA PENERIMAAN MAHASISWA BARU UNIVERSITAS NEGERI JAKARTA TAHUN 2018
}

\author{
Arasy Zamanullail ${ }^{1}$, Hamidillah Ajie ${ }^{2}$, M. Ficky Duskarnaen ${ }^{3}$ \\ ${ }^{1}$ Mahasiswa Prodi Pendidikan Teknik Informatika dan Komputer, Teknik Elektro, FT - UNJ \\ ${ }^{2,3}$ Dosen Prodi Pendidikan Teknik Informatika dan Komputer, Teknik Elektro, FT - UNJ \\ arasyzamanullail16@gmail.com, ${ }^{2}$ hamidillah@unj.ac.id, ${ }^{3}$ duskarnaen@unj.ac.id
}

\begin{abstract}
Abstrak
Penelitian ini dilakukan dengan tujuan untuk membuat suatu media informasi yang berisikan tentang informasi data penerimaan mahasiswa baru Universitas Negeri Jakarta pada tahun 2018. Pendekatan yang digunakan dalam penelitian ini adalah pendekatan Research and Development atau penelitian dan pengembangan. Sedangkan dalam mengembangkan produk digunakan model pengembangan Luther. Penelitian ini dilakukan sejak April 2019 sampai July 2019 bertempat di Universitas Negeri Jakarta. Data mahasiswa yang digunakan dalam penelitian ini didapat dari UPT TIK Universitas Negeri Jakarta, UKT Dikti, BPA tahun 2012 dan objek penelitian ini adalah Calon mahasiswa Universitas Negeri Jakarta.
\end{abstract}

Kata kunci : Motion Graphic, Media Informasi, Data Penerimaan Mahasiswa Baru

\section{Pendahuluan}

\subsection{Latar Belakang}

Pendidikan menjadi hal yang sangat penting bagi setiap orang, terutama untuk menambah ilmu dan wawasan. Pendidikan sendiri memiliki jenjang atau tingkatan tertentu bagi mereka yang ingin menempuhnya. Melalui pendidikan, wawasan seseorang akan semakin maju. Hal ini tentu memberi begitu banyak manfaat bukan hanya secara individu, melainkan juga bagi negara pada umumnya. Melalui pendidikan, banyak orang yang menemukan potensi diri dan mampu mengasahnya untuk menjadi seorang profesional. Salah satu manfaat pentingnya pendidikan adalah untuk membentuk generasi yang berwawasan luas dan yang pasti berguna bagi negara. Ilmu yang diperoleh dalam pendidikan, mampu membantu seseorang untuk menjadi seorang ahli dalam berbagai bidang yang ingin mereka tekuni.

Setelah melewati jenjang pendidikan SD (Sekolah Dasar), SMP (Sekolah Menengah Pertama), SMA (Sekolah Menengah Atas) atau sederajat seperti SMK (Sekolah Menengah Kejuruan) pelajar dapat melanjutkan ke jenjang pendidikan tinggi yang disediakan oleh perguruan tinggi. Dengan banyaknya calon mahasiswa yang ingin melanjutkan pendidikan ke jenjang perguruan tinggi maka munculah kebutuhan akan media informasi tentang perguruan tinggi yang akan dituju.

Universitas Negeri Jakarta menjadi salah satu pilihan utama untuk para calon mahasiswa yang khususnya berada di Jakarta. Dan Universitas Negeri Jakarta ini juga memiliki beberapa fakultas, jurusan, dan program studi yang tersedia sehingga calon mahasiswa dapat memilih sesuai keinginannya. Seiring dengan banyaknya calon mahasiswa yang ingin melanjutkan studi ke Universitas Negeri Jakarta maka media informasi yang mencakup informasi tentang Universitas Negeri Jakarta dibutuhkan.

Sebelum melakukan penelitan penulis menanyakan pertanyaan singkat kepada beberapa teman tentang informasi mengenai Universitas Negeri Jakarta, penulis menanyakan berapa fakultas yang ada di Universitas Negeri Jakarta, Program studi apa saja yang ada, dan berapa banyak mahasiswa setiap program studinya. Dan jawabannya adalah mereka menyatakan tidak mengetahui padahal mereka sudah melaksanakan kuliah di Universitas Negeri Jakarta selama beberapa tahun.

Perkembangan teknologi sangat memungkinkan kita untuk menyebarkan informasi secara mudah dan efisien melalui internet. Internet merupakan salah satu sarana penyebaran informasi yang sangat popular saat ini. Penyebaran informasi melalui 
internet sangat efisien dikarenakan penyebaran bisa terjadi secara cepat dan mencakup jangkauan yang luas selama kita dapat mengakses internet.

Sarana Multimedia dan Animasi sebagai alat komunikasi dan informasi mempunyai peranan yang sangat penting dalam menginformasikan suatu peristiwa kepada masyarakat, hal ini dinilai sangat komunikatif dan efektif di saat mobilitas manusia yang semakin tinggi sehingga dibutuhkan bentuk media komunikasi dan promosi yang menarik dan lebih interaktif yang ditujukan kepada masyarakat, dan banyak cara untuk menyampaikan suatu informasi yang diolah ke dalam bentuk multimedia dan animasi agar terlihat lebih menarik dalam penyampaiannya.

Menurut Arief S. Sadiman (2009: 74) menyatakan video adalah media audio visual yang menampilkan gambar dan suara. Pesan yang disajikan bisa berupa fakta (kejadian, peristiwa penting, berita) maupun fiktif (seperti misalnya cerita), bisa bersifat informatif, edukatif maupun instruksional. Dan menurut Umam (2016: 8) motion graphic merupakan salah satu cabang ilmu desain grafis, dimana dalam motion, elemen - elemen desain seperti bentuk, raut, ukuran, arah, tekstur yang terdapat di dalamnya, dengan secara sengaja digerakkan atau diberi pergerakan agar tampak hidup. Perbedaan motion graphic dengan desain grafis adalah pada media aplikasinya, apabila pada desain grafis elemen-elemennya statis (diam) dan terdapat pada media cetak, sementara motion graphic, elemen dari desain tersebut diberi gerakan sehingga terlihat dinamis dan ditampilkan melalui media audio visual.

Maka dari itu untuk dapat menghasilkan media informasi yang bermanfaat bagi calon mahasiswa Universitas Negeri Jakarta, penulis akan membuat produk Video Motion Graphic tentang Data Penerimaan Mahasiswa Baru Universitas Negeri Jakarta Tahun 2018.

\subsection{Identifikasi Masalah}

Berdasarkan latar belakang diatas, maka dapat diidentifikasi masalah sebagai berikut:

1. Informasi tentang data penerimaan mahasiswa baru selalu mengalami perubahan.

2. Belum adanya media informasi kepada calon mahasiswa yang menyampaikan data hasil proses penerimaan mahasiswa baru.

\subsection{Rumusan Masalah}

Berdasarkan latar belakang yang telah diuraikan, dapat dirumuskan masalah sebagai berikut: Bagaimana memproduksi dan menyusun materi yang diperlukan dalam video motion graphic "Video Motion Graphic Data Penerimaan
Mahasiswa Baru Universitas Negeri Jakarta Tahun 2018?"

\subsection{Tujuan Penelitian}

Tujuan penelitian ini adalah untuk membuat produk video motion graphic berjudul "Video Motion Graphic Data Penerimaan Mahasiswa Baru Universitas Negeri Jakarta Tahun 2018"

\subsection{Lingkup Masalah}

Produk yang dikembangkan hanya menampilkan data mahasiswa tingkat S1 dan D3 yang diterima pada tahun 2018.

\section{Dasar Teori}

\subsection{Video}

Istilah video sendiri berasal dari _eraka latin yang artinya "Saya Melihat" (Amir H. Sulaiman, 1985: 12). Berdasarkan yang dikutip dari (Robert Heinich, 1996: 102) video merupakan salah satu media yang berisi gambar gerak yang memiliki sifat khusus dalam memanipulasi waktu dan tempat. Sukiman (2012: 187-188) menyatakan media video pembelajaran adalah seperangkat komponen atau media yang mampu menampilkan gambar sekaligus suara dalam waktu bersamaan.

Menurut Iwan Binanto (2010:179) Kata video berasal dari kata latin, yang berarti 'saya lihat'. Video adalah teknologi pemrosesan sinyal elektronik yang mewakili gambar bergerak. Aplikasi umum dari teknologi video adalah televisi. Video juga dapat digunakan dalam aplikasi_eraka, keilmuan, produksi, dan keamanan. Istilah video juga digunakan sebagai singkatan videotape, perekam video, dan pemutar video.

Dapat ditarik kesimpulan bahwa video adalah seperangkat komponen yang mampu menampilkan gambar serta suara dalam waktu yang bersamaan yang terbentuk dari sinyal elektronik diproses menjadi gambar bergerak dan memiliki sifat memanipulasi waktu dan tempat.

\subsection{Animasi}

Menurut Vaughan (2004) dalam Iwan Binanto (2010), animasi adalah usaha untuk membuat presentasi statis menjadi hidup. Animasi merupakan perubahan visual sepanjang waktu yang memberi kekuatan besar pada proyek multimedia dan halaman web yang dibuat. Menurut Agus Suheri (2006:2), Animasi adalah kumpulan gambar yang diolah sedemikian rupa sehingga menghasilkan gerakan.

Animasi berasal dari kata "to animate" yang artinnya menggerakan. Animasi sendiri merupakan suatu peraka menampilkan gambar berurutan sedemikian rupa sehingga penonton merasakan 
adanya ilustrasi gerakan (motion) pada gambar yang ditampilkan. Animasi adalah hasil dari proses menampilkan obyek-obyek gambar sehingga gambar yang ditampilkan akan tampak hidup. Tidak hanya menghidupkan, animasi juga memberikan karakter kepada obyek-obyek tersebut (Binanto,2010).

Berdasarkan pengertian diatas dapat diambil kesimpulan bahwa animasi adalah sekumpulan gambar yang tersusun secara beraturan mengikuti pola pergerakan yang telah ditentukan pada hitungan waktu tertentu sehingga gambar yang sebenarnya statis kelihatan menjadi hidup.

\subsection{Motion Graphic}

Menurut Al Boardman dalam artikelnya "What is Motion Graphics?" menjelaskan "Motion graphics is a digital technique that combines pictures, words, sound and video" yang artinya adalah motion graphic adalah sebuah teknik digital yang mengkombinasikan gambar, kata-kata suara kedalam bentuk video.

Dia kemudian melanjutkan bahwa motion graphic menggabungkan animasi, dan desain grafis pada film. Dengan menggabungkan berbagai elemen kreatif yang berbeda seperti tipografi, gambar ilustrasi, bentuk, dan logo kedalam sebuah video. Lalu, mereka di animasikan dan digerakkan sehingga menceritakan sebuah cerita.

Menurut Umam (2016: 8) Motion graphic merupakan salah satu cabang ilmu desain grafis, dimana dalam motion, elemen - elemen desain seperti bentuk, raut, ukuran, arah, tekstur yang terdapat di dalamnya, dengan secara sengaja digerakkan atau diberi pergerakan agar tampak hidup. Perbedaan Motion graphic dengan desain grafis adalah pada media aplikasinya, apabila pada desain grafis elemen - elemennya statis (diam) dan terdapat pada media cetak, sementara Motion graphic, elemen dari desain tersebut diberi teknik sehingga terlihat dinamis dan ditampilkan melalui media audio visual.

Sukarno (2008:2) dalam Tugas akhirnya menjelaskan: Menurut Ahli Teori Perfilman Michael Betancourt, dalam artikelnya yang berjudul The Origins of Motion Graphics, yang terdapat di Cinegraphic pada tanggal 6 Januari 2012, motion graphic adalah media yang menggunakan rekaman video dan / atau teknologi animasi untuk menciptakan ilusi gerak dan biasanya dikombinasikan dengan audio untuk digunakan dalam sebuah output multimedia. Motion graphic biasanya ditampilkan melalui teknologi media elektronik, tetapi dapat ditampilkan melalui petunjuk didukung teknologi (misalnya thaumatrope, phenakistoscope, stroboscope, zoetrope, praxinoscope, dan flip book juga). Istilah ini berguna untuk membedakan still graphics dari grafis dengan penampilan yang berubah dari waktu ke waktu (transforming graphics).

Dari penjelasan diatas dapat diambil kesimpulan bahwa Motion graphic adalah teknik animasi yang menggabungkan elemen-elemen seperti tipografi, gambar ilustrasi, logo, suara, kedalam satu buat komposisi yang berisi informasi untuk diceritakan biasanya ditampilkan melalui media elektronik walaupun tidak menutup kemungkinan ditampilkan melalui petunjuk seperti flipbook.

\subsection{Flat Design}

Menurut Wiyancoko (2010) desain adalah segala hal yang berhubungan dengan pembuatan konsep, analisis data, project planning, drawing/rendering, cost calculation, prototyping, frame testing, dan test riding. Menurut Soekarno \& Basuki (2008) Desain adalah pola rancangan yang menjadi dasar pembuatan suatu benda, seperti busana.

Menurut arti kata flat berarti datar. Bangun datar dapat didefinisikan sebagai bangun yang rata yang mempunyai dua demensi yaitu panjang dan lebar, tetapi tidak mempunyai tinggi atau tebal (Julius Hambali, Siskandar, dan Mohamad Rohmad : 1996).

Dapat ditarik kesimpulan bahwa flat design adalah konsep pembuatan pola rancangan yang menjadi dasar pembuatan suatu media yang terdiri dari bangun-bangung dua dimensi.

\section{Metodologi}

\subsection{Implementasi Perangkat Keras}

Spesifikasi perangkat keras yang digunakan dalam rekayasa dan implementasi produk video motion graphic ini adalah sebagai berikut:

$\begin{array}{ll}\text { Processor } & : \text { Intel Core i5 } \\ \text { Hard Drive } & : 1000 \text { GB SATA } \\ \text { Memory } & : 16 \text { GB } \\ \text { Monitor } & : 13 "\end{array}$

\subsection{Implementasi Perangkat Lunak}

Spesifikasi perangkat lunak yang digunakan dalam rekayasa dan implementasi produk video motion gaphic ini adalah sebagai berikut: Operating System: Mac OS X Yosemite Video Editor : Adobe After Effect CC 2017 Image Editor : Adobe Illustrator CS6

\subsection{Konsep Pengembangan Produk}

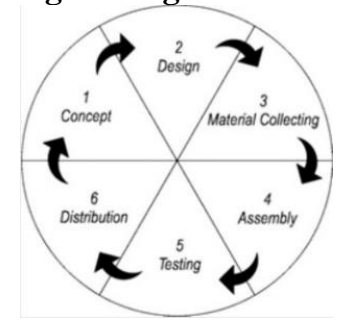


Gambar Error! No text of specified style in document..1. Diagram Konsep Pengembangan

Menurut Luther (Dalam Binanto ; 2010:259263), metodologi pengembangan multimedia terdiri dari enam tahap, yaitu concept (konsep), design (desain), material collecting (pengumpulan materi), assembly (pembuatan), testing (pengujian), dan distribution (pendistribusian). Biasanya setelah tahap distribution akan muncul masalah-masalah baru sebagai bahan pembaharuan untuk produk yang dibuat, untuk itu Sutopo kemudian memberkan modifikasi dalam tahapan pengembangan Luther. Pada konsep pengembangan Luther tahapan berhenti sampai di distribution, namun kemudian Sutopo menambahkan lanjutan tahapan dari tahap distribution kembali ke tahap concept. Berdasarkan gambar 2.1 dapat dilihat bahwa setelah tahap distribution dapat kembali lagi ke tahap concept sehingga produk yang dibuat senantiasa dapat dilakukan perbaikan jika dibutuhkan dimasa mendatang. Metode pengembangan Luther-Sutopo memiliki kelebihan dan kekurangan sebagai berikut:

1) Kelebihan

Memungkinkan untuk dilakukan pembaharuan jika dibutuhkan dimasa mendatang.

2) Kekurangan

Biasanya pengembangan dilakukan secara sederhana, karena produk rentan terhadap perubahan selama masa pengembangan dan hasil sesungguhnya hanya dapat dilihat jika sudah sampai tahap penyelesaian.

Tahapan yang terdapat dalam metodologi pengembangan Lther-Sutopo adalah sebagai berikut:

\section{1) Concept}

Tahap concept (pengonsepan) adalah tahap untuk menentukan tujuan dan siapa pengguna program (identifikasi audiens). Tujuan dan pengguna akhir program berpengaruh pada nuansa multimedia sebagai pencerminan dari identitas organisasi yang menginginkan informasi sampai pada pengguna akhir. Karakteristik pengguna termasuk kemampuan pengguna juga perlu dipertimbangkan karena dapat mempengaruhi pembuatan desain.

Tahap ini merupakan tahap paling penting dalam pembuatan produk multimedia karena setelah tahap ini terpenuhi maka peneliti langsung dapat mengerjakan bagiannya masing-masing tanpa harus menunggu tahapan lainnya selesai terlebih dahulu.

2) Design

Design (perancangan) adalah tahap pembuatan spesifikasi mengenai arsitektur video, gaya, tampilan dan kebutuhan material/bahan untuk video.
Spesifikasi dibuat serinci mungkin sehingga pada tahap berikutnya, yaitu material collection dan assembly, pengambilan keputusan baru tidak diperlukan lagi, cukup menggunakan keputusan yang sudah ditentukan pada tahap ini. Meskipun demikian, pada akhirnya pengerjaan proyek pada tahap awal masih akan sering mengalami penambahan bahan atau pengurangan bagian aplikasi atau perubahan-perubahan lain. Tahapan ini biasanya menggunakan storyboard untuk menggambarkan deskripsi tiap scene, dengan mencantumkan semua objek multimedia dan tautan ke scene lain dan bagan alir (flowchart) untuk menggambarkan aliran dari satu scene ke scene lain.

\section{3) Material Collection}

Material collection adalah tahap pengumpulan bahan yang sesuai dengan kebutuhan yang dikerjakan. Bahan-bahan tersebut antara lain gambar clip art, foto, animasi, video, audio dan lain-lain yang dapat diperoleh secara gratis atau dengan pemesanan kepada pihak lain sesuai dengan rancangannya. Tahap ini dapat dikerjakan secara paralel dengan tahap assembly. Namun, pada beberapa kasus, tahap material collection dan tahap assembly akan dikerjakan secara linear dan tidak paralel.

\section{4) Assembly}

Tahap assembly adalah tahap penyatuan semua objek atau bahan multimedia. Pembuatan aplikasi didasarkan pada tahap design, seperti storyboard, bagan alir, dan struktur navigasi. Tahap ini biasanya sudah menggunakan media perangkat lunak authoring seperti Macromedia Director, Macromedia Flash Adobe After Effect CS6 dan lainlain.

\section{5) Testing}

Tahap testing (pengujian) dilakukan setelah menyelesaikan tahap pembuatan (assembly) dengan menjalankan produk video dan melihatnya apakah ada kesalahan atau tidak. Tahap pertama pada tahap ini disebut tahap pengujian alpha (alpha test) yang pengujiannya dilakukan oleh pembuat atau lingkungan pembuatnya sendiri. Setelah lolos dari pengujian alpha, pengujian beta yang melibatkan pengguna akhir akan dilakukan.

\section{6) Distribution}

Pada tahap ini, aplikasi akan disimpan dalam suatu format media penyimpanan. Jika media penyimpanan tidak cukup untuk menampung aplikasinya, kompresi terhadap aplikasi tersebut akan dilakukan. Tahap ini juga dapat disebut tahap evaluasi untuk pengembangan produk yang sudah jadi supaya menjadi lebih baik. Hasil evaluasi ini 
dapat digunakan sebagai masukan untuk tahap concept pada produk selanjutnya.

\subsection{Storyline}

Storyline merupakan rancangan kasar sedangkan storyboard merupakan rancangan yang lebih terpadu. Storyline adalah naskah singkat yang diambil dari gagasan utama dalam sebuah cerita yang dibuat seperti alur cerita.

Storyline produk ini adalah sebagai berikut :

1) Intro video

2) Menampilkan alamat kampus-kampus UNJ.

3) Menampilkan rentang golongan UKT Mahasiswa yang diterima pada tahun 2018.

4) Menampilkan pertumbuhan penerimaan mahasiswa baru UNJ dari tahun 2014-2018.

5) Menampilkan jumlah mahasiswa yang diterima pada tahun 2017.

6) Menampilkan jumlah mahasiswa yang diterima dipisahkan berdasarkan jalur penerimaan.

7) Menampilkan jumlah mahasiswa yang diterima berdasarkan wilayah asal.

8) Intro Fakultas.

9) Jumlah mahasiswa yang diterima berdasarkan fakultas dibagi menjadi total seluruh dan total masing-masing jalur penerimaan.

10) Jumlah mahasiswa yang diterima berdasarkan jalur penerimaan masing-masing program studi yang terdapat di masing-masing fakultas.

\subsection{Konsep Visual}

Pengonsepan yaitu menentukan tujuan sasaran dari produk yang dibuat serta spesifikasi umum dalam pembuatan produk. Dasar aturan untuk perancangan juga ditentukan pada tahap ini, seperti ukuran file, format, durasi, dan materi atau informasi apa saja yang akan ditayangkan pada produk video motion graphic. Konsep inilah yang akan dijadikan gambaran umum dalam pengerjaan media informasi tentang Data Penerimaan Mahasiswa Baru Universitas Negeri Jakarta tahun 2018.

Tema yang digunakan dalam pembuatan video ini adalah flat design. Flat design merupakan tipe desain yang tidak memiliki terlalu banyak elemen. Oleh karena itu hasil kompresi dari video yang dihasilkan biasanya tidak terlalu besar. Hal ini sangat menguntukan jika video yang dibuat dimaksudkan untuk disebarkan melalui media internet, karena resipien tidak memerlukan pengunduhan data yang terlampau besar.

Flat design sendiri memiliki ciri yang menggunakan palate warna yang terbilang redup, oleh karena itu warna kuning yang termasuk kedalam kelompok warna terang kurang cocok digunakan dalam video ini. Selain itu digunakan juga warna merah dan warna biru pada sebagian elemen video. Video ini tidak menggunakan narasi karena jika ditayangkan pada layar-layar yang terdapat di gedung fakultas biasanya tidak memiliki speaker. Serta tidak memiliki closing karena akan diputar secara terus menerus (loop).

\section{Teknik Pengumpulan Data}

Teknik pengumpulan data yang digunakan pada penelitian dan pengembangan video motion graphic data penmaba Universitas Negeri Jakarta tahun 2018 adalah dengan teknik wawancara. Teknik wawancara yang digunakan dalam penelitian ini adalah teknik wawancara terstruktur. Menurut Sugiyono (2015:211) dalam melakukan wawancara tersetruktur, pengumpul data telah menyiapkan instrumen penelitian berupa pertanyaanpertanyaan tertulis yang alternatif jawabannya telah disiapkan. Wawancara terstruktur ini dilakukan kepada staf UPT TIK Universitas Negeri Jakarta, ahli media, ahli materi. Penulis juga mengambil data dari UKT dikti dan BPA tahun 2012 Universitas Negeri Jakarta

\section{Hasil dan Analisis}

\subsection{Implementasi Video}

\subsubsection{Intro video}

Intro video menampilkan judul video yaitu "Data Penerimaan Mahasiswa Baru S1 dan D3Tahun 2018" dilanjutkan dengan menampilkan nama universitas serta logo.

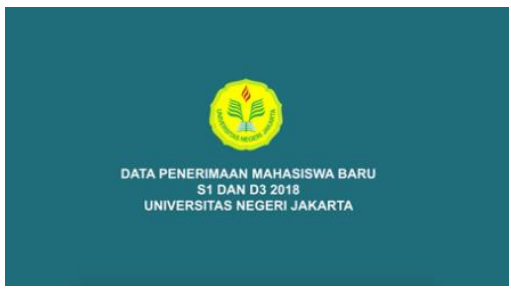

Gambar 4.1. Tampilan intro video

\subsubsection{Alamat Kampus UNJ}

Bagian selanjutnya menampilkan alamat kampus-kampus UNJ.

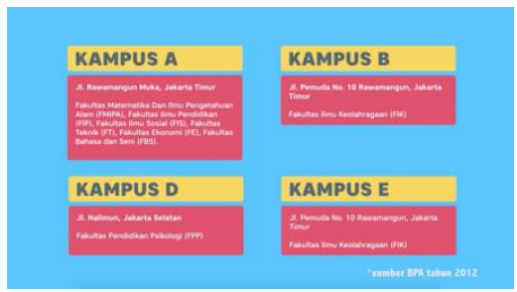

Gambar 4.2. Tampilan alamat kampus UNJ 
4.1.3 Golongan UKT mahasiswa yang diterima pada tahun 2017

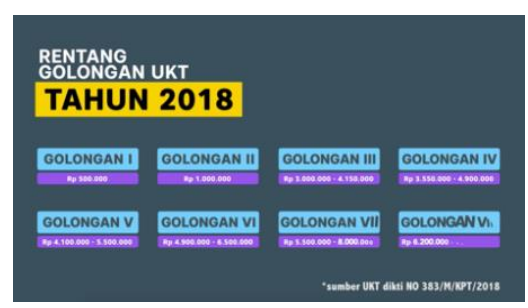

Gambar 4.3. Tampilan golongan UKT

\subsubsection{Data Penmaba UNJ Tahun 2018}

Pada bagian ini dijelaskan data penerimaan mahasiswa UNJ pada penmaba 2018 yang lalu dibagi menjadi pertumbuhan jumlah penerimaan dari tahun 2014-2018 (secara keseluruhan), total mahasiswa S1 dan D3. Kemudian dibagi berdasarkan jalur penerimaan yaitu SNMPTN, SBMPTN dan Mandiri.

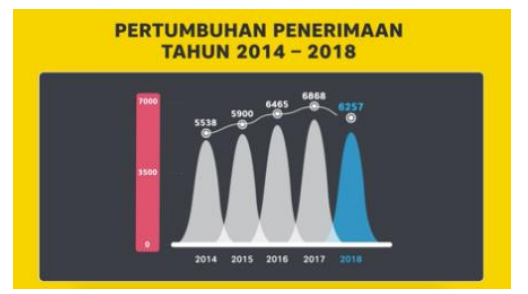

Gambar 4.4. Tampilan pertumbuhan penerimaan

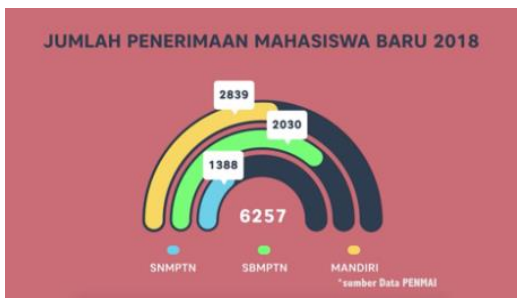

Gambar 4.5. Tampilan jumlah penerimaan Maba

\subsubsection{Data Penmaba UNJ Berdasarkan Wilayah} Asal Pendaftar

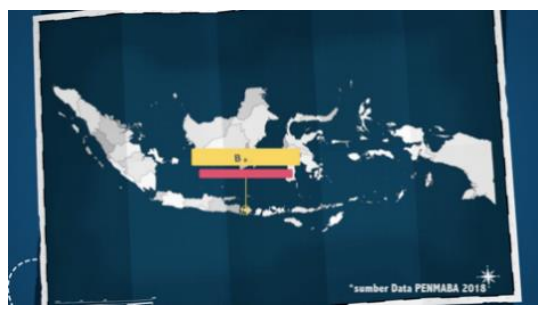

Gambar 4.6. Tampilan data Penmaba UNJ
4.1.6 Data Mahasiswa yang Diterima Berdasarkan Fakultas dan Program Studi

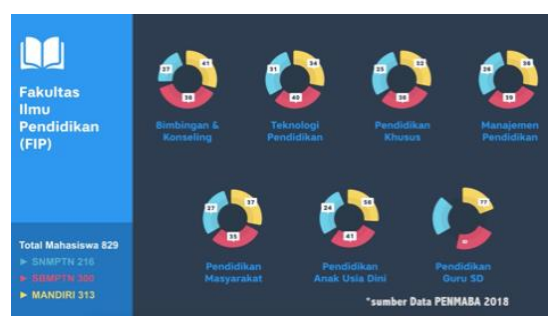

Gambar 4.7. Tampilan data mahasiswa diterima

Pada bagian ini menampilkan data mahasiswa yang diterima dibagi menjadi per fakultas. Dari total data penerimaan fakultas dibagi lagi menjadi 3 berdasarkan jalur penerimaan. Setelah itu menampilkan data mahasiswa yang diterima berdasarkan masing-masing program studi.

Sejak penerimaan mahasiswa baru tahun 2017 UNJ memiliki 1 fakultas tambahan yaitu Fakultas Psikologi. Awalnya Psikologi merupakan bagian dari Fakultas Ilmu Pendidikan.

Selama dalam proses penelitian, pengembangan serta implementasi produk video tentang data penerimaan mahasiswa baru Universitas Negeri Jakarta tahun 2017 terdapat beberapa faktor pendukung dan faktor penghambat, diantaranya:

1) Faktor pendukung

a. Setiap fakultas di Universitas Negeri Jakarta memiliki alat pendukung untuk menampilkan produk berupa layar.

b. Media informasi berupa video dapat disebarkan dengan secara lebih luas melalui pemanfaatan media internet.

2) Faktor penghambat

Proses pengembangan produk menggunakan perangkat keras yang memiliki spesifikasi terbilang batas minimum sehingga terkadang mengalami hambatan saat proses penyusunan.

\section{Kesimpulan dan Saran}

\subsection{Kesimpulan}

1. Produk ini diproduksi dengan menggunakan 2 software adobe after effect CS6 untuk video editing dan adobe illustrator CS6 untuk vector image editing. Produk ini berupa gambar, grafik, teks, transisi serta musik yang membuatnya menjadi menarik sebagai media informasi.

2. Penulis menggunakan model proses pengembangan unuk multimedia yang 
mengacu pada Multimedia Development life cycle (MDLC) dengan tahapan konsep, perancangan, pengumpulan bahan, perakitan, pengujian dan distribusi.

3. Hasil pengujian ahli materi mendapatkan skor 9 dari 9 jumlah skor maksimum yang menyatakan bahwa produk yang telah dibuat memiliki materi yang sesuai dan layak untuk lanjut ke tahap selanjutnya, dari ahli media penulis mendapatkan skor 46 dari 50 skor maksimum dengan nilai skor akhir $92 \%$ produk dapat dinyatakan sangat baik dan bisa lanjut untuk ditayangkan kepada para calon mahasiswa dan terakhir uji evektivitas produk terbagi menjadi dua yaitu uji kelompok kecil dan uji kelompok besar. Uji kelompok kecil dilakukan terhadap 5 orang responden. Berdasarkan hasil yang didapat dari uji kelompok kecil didapatkan nilai sebesar $95 \%$. Dari uji kelompok besar didapatkan nilai sebesar 96\%. Dangan nilai ini dinyatakan produk sudah siap digunakan.

\subsection{Saran}

Untuk pengembang selanjutnya, berikut adalah hal-hal yang disarankan oleh peneliti guna memperbaiki dan mengembangkan produk lebih jauh, antara lain:

1. Sesuaikan logo dan ciri khas setiap fakultas lebih dalam agar video lebih menarik dan mudah dipahami

2. Tambahkan cara untuk mendaftarkan diri mengikuti jalur ujian yang tersedia.

3. Tampilkan peminat dari setiap program studi dan buat perbandingan berapa orang yang diterima.

\section{Daftar Pustaka:}

Umam, N. C. (2016) Perancangan Motion Graphic Pengenalan Batik Gemawang Karya Khas Kabupaten Semarang. [Jurnal]. Fakultas Seni Rupa, Institut Seni Yogyakarta.

Binanto, I. (2010). Multimedia Digital - Dasar Teori dan Pengembangan. Yogyakarta: Penerbit Andi.

Sukiman. (2012). Pengembangan Media Pembelajaran. Yogyakarta: Pedagogia.

Sulaiman, A. H. (1985) Media Audio Visual Untuk Pengajaran, Penerangan dan Penyuluhan. Jakarta: PT Gramedia.

Sukarno, I. S. (2008). Perancangan Motion Graphic Ilustratif Mengenai majapahit Untuk Pemuda-pemudi. [Jurnal]. Fakultas Seni Rupa dan Desain, Institut Teknologi Bandung.
Heinrich, R. (1993). Insructional Media and The New Technologies of Instruction. New York: Mcmillan Publishing.

Luther, A. C. (1994). Authoring Interactive Multimedia. Massachusettes: Academic Press, Inc.

Suheri, A. (2006). "Animasi Multimedia Pembelajaran". Jurnal Animasi Multimedia. Pembelajaran. 2, (1), 27-33.

Boardman, Al. http://www.alboardman.com/what-ismotion-graphics/. Diakses pada 15 Agustus 2017.

Vaughan, T. (2004). "Multimedia: Making It Work”, Edisi 6, Yogyakarta: Penerbit Andi.

Soekarno \& Basuki, L. (2008). Panduan Membuat Desain Ilustrasi Busana (Teknik Dasar, Terampil, dan Mahir). Jakarta: Kawan Pustaka.

Wiyancoko, D. (2010), Desain Sepeda Indonesia, Jakarta: KPG (Kepustakan. Populer Gramedia) 